\title{
Surfacing Identity of Pre-Service Teachers at the Brink of ICT- Based Teaching in the 21st Century
}

\author{
Ronald Candy Santos Lasaten \\ Associate Professor II \\ Mariano Marcos State University, College of Teacher Education, Laoag City \\ ronaldlasaten@gmail.com
}

\begin{abstract}
Using the descriptive-correlational research design, the study aimed to describe the pre-service teachers' attitudes towards ICT-based teaching, their perceived readiness and their technological practices in education and determine their degree of relationship with their levels of knowledge on ICT-based instruction. The study involved 285 pre-service teachers of the Mariano Marcos State University College of Teacher Education, Laoag City, Ilocos Norte. A self-assessment checklist was used to gather the needed data. The pre-service teachers' levels of knowledge on ICT-based instruction were based on their grades in Educational Technology 2 which focuses on ICT integration. Data gathered were treated using mean and chi-square test of independence. Findings reveal that the pre-service teachers think positively towards the use of ICT in teaching and in learning. It is also revealed that the pre-service teachers are moderately ready in terms of using ICT-based strategies and techniques as regards general performance, skills, competencies and internet sourcing. Further, the pre-service teachers think that they are good enough as practitioners of ICT. However, findings show that the levels of knowledge of the pre-service teachers about ICT-based teaching do not significantly relate with their attitudes, perceived readiness, and ICT practices. The study concluded that the pre-service teachers' have positive attitude towards ICT-based teaching. The pre-service teachers are prepared to face their student s' learning concerns. They, too, have good ICT practices. Further, the preservice teachers' levels of knowledge on ICT-based teaching have no relationship with their attitudes towards ICT-based teaching, their perceived readiness and their ICT practices.
\end{abstract}

Keywords: Pre-service teachers, ICT-based teaching, attitude, technological practices, perceived readiness, level of knowledge on ICT-based instruction

\section{INTRODUCTION}

The only permanent thing in this world is change. Practices, habits and even beliefs of people constantly change. The things that they use to make life easier have shifted to more sophisticated ones. Ways and means get better and faster each time. All these are because of technology.

As fresh minds hunger for knowledge and learning, education, too, moves at par with the rapidly growing world of expertise. Educational technology occupies the center stage in the state-of-the-art hypermedia instruction. Schools, colleges and universities have been utilizing various educational approaches in carrying out their principles of learning and their visions of development. Teachers, specifically, have started to integrate ICT into their instruction to a belief that ICT-based teaching will improve the teaching learning process. Such shift in teaching has challenged teachers to update their strategies and techniques in causing learning using technology in education. 
According to the Association for Educational Communications and Technology, Washington DC, USA, as cited by Corpuz and Lucido (2008), educational technology is a complex, integrated process involving people, procedures, ideas, devices, and organization for analyzing problems and devising, implementing, evaluating, and managing solutions to those problems, involved in all aspects of human learning.

Indeed, educational technology has determined how the learning environment in the formal schools developed into a more competent and highly interactive and analytical educational setting. Instruction has gone far regarding the techniques in teaching since the infusion of computers and the internet in the schools. The traditional chalk board method has seen its giant rival in multi-media instruction. The textbooks have found a total alternative in hypermedia resourcing.

The question is, are the would-be teachers ready to embark with the fast growing technology in education? Are they prepared to utilize the wide range of computer software, educational applications, multimedia and hyper-media resources from the net and World Wide Web to maximize the teaching-learning experience? Could they be able to manage ICT tools in teaching? Are they ready enough to face the challenge?

Roblyer and Edwards (2000) state that a teacher should develop a philosophy of technology which is integrated in the instruction. As new generations of students take place in the academe, newer and more updated demands come about. Each year, the teacher updates his technological methods to meet the growing exigencies. The teacher sets at least a foot ahead of the students as far as technological growth is concerned.

The pre-service teacher's learning experiences in the University are an excellent, if not the ultimate, opportunity to prepare himself for a functional ICT-based instruction. While his attitude determines how much he could achieve the competencies, strategies and techniques, actual practice is inevitable to enhance his skills in managing such technology in instruction.

Readiness is a highly variable and complicated word to consider. This entails a number of points to satisfy for an individual to be considered as "ready". It is quite easy to merely say that one is ready to face a certain task. However, along the way, problems arise that would just consequently lead to worse scenarios, hence, the miscalculations of readiness.

Readiness, in the holistic sense, involves the readiness of the mind, heart and the physical body - the cognitive, affective and psychomotor domains, respectively (Schaffer, 2004). Pre-service teachers may be said ready when equipped with the necessary information and knowledge of the teaching strategies (cognitive), the positive attitude to sustain their interest to move on (affective), and congruent manual skills and practices in doing all these ICT tasks in teaching and personal development (psychomotor).

In the Philippine Tertiary Education, pre-service teachers are trained to manage, administer and manipulate ICT-based learning resources. Lucido (2008) expressed that future teachers should develop in themselves higher order thinking skills as they embark with the ICT-based teaching. Using technology does not only allow teachers to make use of any multi-media resources but also requires them to be critical and analytical. Technological teaching is not only exhibiting the wonders of human creation. It is likewise the development of sensible thinking, logical reasoning and creative generalization among students. Therefore, the teacher 
shall possess such in the first place. Their training in college is vital in their formation, thus, an important predictor of their readiness to become effective educational technologists.

The Commission on Higher Education (CHED) of the Philippines side-by-side with the Philippine Association for Teacher Education (PAFTE) reengineered the curricular program of Teacher Education in the tertiary level with the demands of modern technology. In line with this task, technical and professional courses with field study were integrated in the programs for Elementary and Secondary Teacher Education. Information and Communication Technology and Educational Technology courses respond to such demands.

Pre-service teachers are familiarized and equipped with the necessary skills in information and communication technology. Hands-on applications pertinent to the job of the teacher are being provided in the early levels. Teaching strategies and techniques in education complement such skills to prepare and equip pre-service teachers for the real work in the schools.

The researcher believes that this situation can be delayed further should there be enough skilled manpower ready to fit in the ICT world. Thus, this research tried to, at least, identify a certain community of would-be teachers who will soon be competing with the anchor of time the ICT-based teaching.

ICT-based teaching, as defined by Lucido and Borabo (2007) is the integration of the knowledge, skills and attitude in order to cope with the technological learning. The teacher needs to be equipped of the necessary information and basic concepts about ICT and educational technology. These include teaching strategies and content, basic and functional terms, protocols and procedures, learning competencies, software and hardware features and functions, student experiences, and a lot more. These information and inputs are taken up in the tertiary level for teacher education students. The content of ICT-based teaching is thoroughly undergone in technology courses.

Suggested by Morrison and Lowther (2005), ICT-based teaching is not only concerned with the content learning and teaching. It is also concerned with the proper attitude the teacher has to manifest and demonstrate. They claim that technological attitude goes with knowing the roles of the job. These are basically the curriculum developer, the classroom manager and learning evaluator.

The same authors identified the basic skills in ICT-based teaching. The teacher should be adept in word processing, spreadsheets, databases, publishing and presentation, internet resourcing and using educational software as instructional technology, audio-video devices and/or interactive techniques.

Are the three foregoing points characterizing a good ICT-based teacher (knowledge, attitude and skills) are what it takes to equip a pre-service teacher ready to embark with the global demands in education?

With such question in mind, the study aimed to determine and describe the pre-service teachers' attitudes towards ICT-based teaching, their perceived readiness and ICT practices in education. Further, it aimed to determine if such variables have significant relationship with their levels of knowledge on ICT-based teaching. 


\section{METHODOLOGY}

The study used the descriptive-correlational research design. This research design involves collecting information through data review and surveys and describing the way things are with respect to variables or conditions in a situation. In this study, the pre-service teachers' attitudes towards ICT-based teaching, their perceived readiness to carry out ICT-based teaching and their ICT practices in education were described and analyzed and were correlated with their levels off knowledge on ICT-based instruction.

Respondents in the study were the 285 (180 BEEd and 105 BSEd) 4th year pre-service teachers of the Mariano Marcos State University College of Teacher Education located in Laoag City, Ilocos Norte. The said institution is considered one of the Centers of Excellence in the country that produces great number of teacher education graduates in Region 1.

Using a researcher-made self-assessment checklist, the attitudes towards ICT-based teaching, perceived readiness for ICT-based teaching and ICT practices of the identified pre-service teachers were gathered. Meanwhile, the pre-service teachers' levels of knowledge on ICTbased instruction were drawn from their grades in Educational Technology 2 (Ed Tech 2), an educational technology course that responds to the demand of pre-service teachers for skills in ICT integration.

Statistical tools such as mean and chi-square test of independence were used to treat the data gathered.

\section{RESULTS AND DISCUSSIONS \\ Pre-service Teachers' Attitudes towards ICT-based Teaching}

According to Morrison and Lowther (2005), ICT-based teaching is not only concerned with the content learning and teaching but also with the proper attitude the teacher has to manifest and demonstrate. Interestingly, the study looked into this area of concern. Thus, Table 1 presents the attitudes of the pre-service towards the use of ICT in teaching.

Table 1. Attitudes of pre-service teachers towards the use of ICT in teaching

\begin{tabular}{|c|c|c|c|c|c|}
\hline \multirow{2}{*}{$\begin{array}{l}\text { Attitude toward ICT-based } \\
\text { Teaching }\end{array}$} & \multicolumn{3}{|c|}{$\begin{array}{c}\text { Mean response per } \\
\text { Level of Knowledge-Group }\end{array}$} & \multirow[b]{2}{*}{ OVERALL } & \multirow{2}{*}{$\begin{array}{l}\text { Descriptive } \\
\text { Interpretation }\end{array}$} \\
\hline & $\begin{array}{l}\text { Below } \\
\text { Average }\end{array}$ & $e^{\text {Average }}$ & $\begin{array}{l}\text { Above } \\
\text { Average }\end{array}$ & & \\
\hline $\begin{array}{l}\text { 1. ICT is an important tool in teaching } \\
\text { and learning. }\end{array}$ & 4.0 & 4.0 & 4.0 & 4.00 & Highly Favorable \\
\hline $\begin{array}{l}\text { 2. Learning ICT should be continuous. } \\
\text { 3. ICT-based techniques are better } \\
\text { than the traditional means }\end{array}$ & 2.4 & 3.3 & 3.5 & 3.07 & Favorable \\
\hline $\begin{array}{l}\text { (e.g. chalkboard). } \\
\text { 4. Higher-order thinking skills are well }\end{array}$ & 2.5 & 2.8 & 3.1 & 2.82 & Favorable \\
\hline achieved through the use of ICT. & 2.9 & 3.2 & 3.0 & 3.04 & Favorable \\
\hline of information over library works. & 3.3 & 2.9 & 2.8 & 2.96 & Favorable \\
\hline
\end{tabular}

From the table, it can be deemed that the pre-service teachers generally think positively about the use of ICT in teaching and in learning. They are highly favorable with the idea that ICT is an important tool to education as indicated by the overall mean of 4.00 . Furthermore, the preservice teachers have favorable attitude with the ideas that learning ICT should be continuous and higher-order thinking skills are well-achieved through the use of ICT as shown by the overall means of 3.07 and 3.04, respectively. Though positively perceived, the pre-service 
teachers still believe that traditional means of teaching and learning such as the use of the library (2.96) and the use of chalkboard (2.82) are as equal as the use of ICT tools.

The result means that the pre-service teachers have positive attitude towards ICT-based teaching and learning. However, they still find the traditional methods of teaching and learning significant as compared with the use of ICT tools in the teaching and learning process. This only implies that the pre-service teachers have not yet totally ignored the importance of traditional methods of teaching and learning, yet they are open to embrace ICT tools in teaching and learning.

\section{Pre-service Teachers' Perceived Readiness for ICT-based Teaching}

The following table presents the perceived readiness of the pre-service teachers in using ICT tools in teaching.

Table 2. Perceived readiness of pre-service teachers in ICT-based teaching

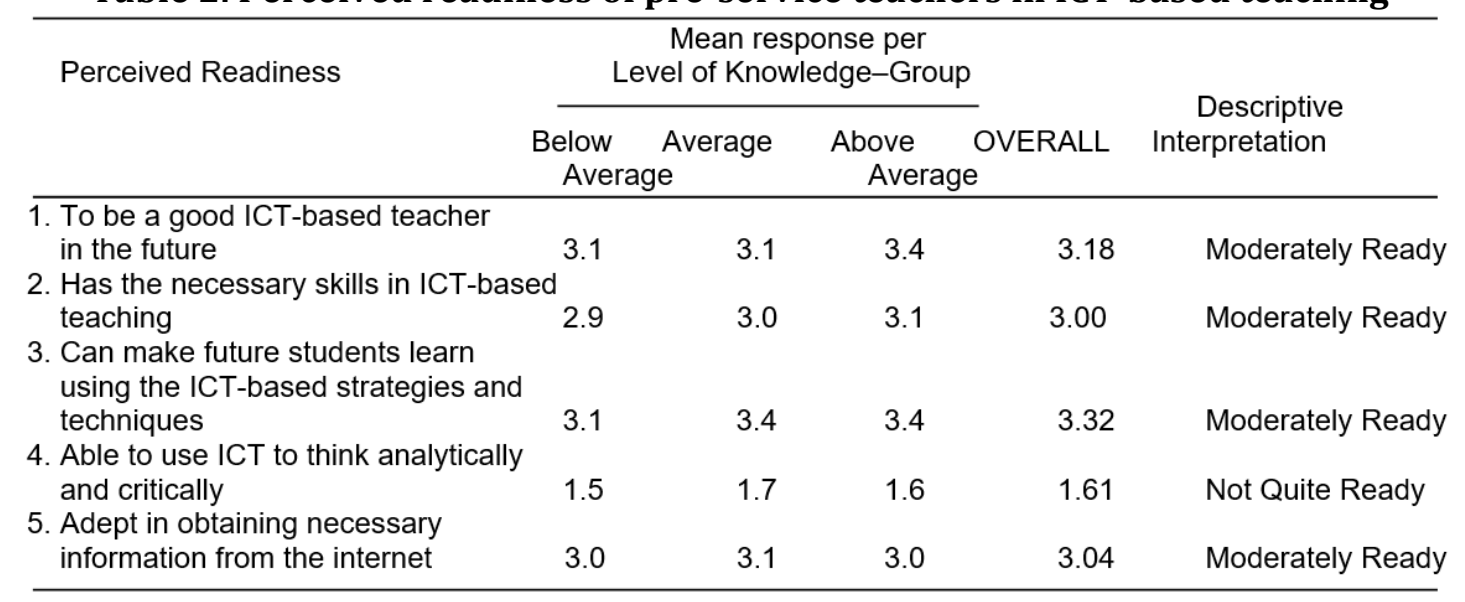

The table shows that the pre-service teachers are moderately ready for ICT-based teaching, particularly on making future students learn using ICT-based strategies and techniques (3.32), becoming a good ICT-based teacher in the future (3.18), obtaining necessary information from the internet (3.04), and having necessary skills in ICT-based teaching (3.00). However, they are not quite ready to translate the practices they have into motivational means to make their future students think analytically and critically as shown by the mean score of 1.61.

The data suggest that pre-service teachers do not only need to be equipped with the knowledge, skills, and practices on the technical aspect of ICT to make them well-prepared and trained. They also need to be taught about how these things can be utilized to ladderize the thinking skills of students and cause functional learning.

The results therefore imply that the pre-service teachers are moderately ready in terms of using ICT-based strategies and techniques as regards general performance, skills, competencies and internet sourcing. However, they need more trainings and practice in using ICT to target their students' analytical and critical thinking. Through trainings and practice, they are able to prepare themselves well for ICT-based teaching.

According to Tomei (2002), he affirms that pre-service teachers may only consider themselves ready to the 21 st century ICT-based teaching when they are able to use responsively to the 
demands of their personal and professional growth and their future learners more than the mere presence of highly sophisticated gadgets.

\section{Pre-service Teachers' ICT Practices in Education}

Table 3 presents the ICT practices of the pre-service teachers. Based on the table, the preservice teachers are very good at communicating and transmitting documents through emails, social networks, groups, etc. (3.61), downloading pictures, images, data, clips, articles, etc. necessary for school tasks (3.60), and adept in obtaining necessary information from the internet (3.60). Further, they are good at surfing the internet for educational research (3.43) and doing student-teaching tasks (3.43).

Table 3. Self-assessment of pre-service teachers of their ICT practices for educational purposes

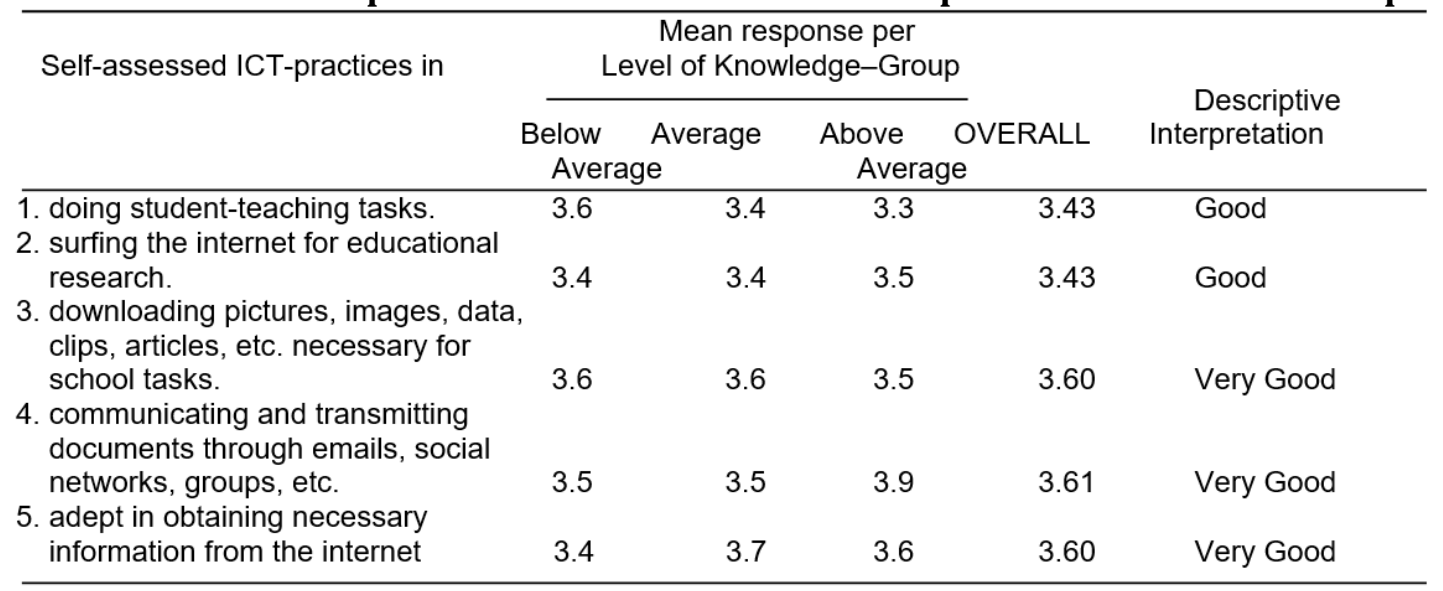

The result implies that the pre-service teachers are generally good in their ICT practices. They are good enough as practitioners of ICT both in their academics and preparation of studentteaching tasks. Such result further implies that they are confident enough in using ICT tools; however, this does not necessarily imply that they are prepared for ICT-based teaching since ICT-based teaching requires principles, theories and pedagogy in the use of ICT tools.

\section{Relationship of the Pre-service Teachers' Knowledge in Educational Technology with their Attitudes, Perceived Readiness and ICT Practices}

Table 4 presents the relationship between the pre-service teachers' knowledge on ICT-based teaching, attitude towards ICT-based teaching, perceived readiness on the use of ICT in teaching, and ICT practices.

Table 4. Relationship of the pre-service teachers' knowledge on ICT-based instruction with their attitudes towards ICT-based teaching, perceived readiness on the use of ICT in teaching, and ICT practices

\begin{tabular}{lcc}
\hline \multicolumn{1}{c}{ Variable } & Chi-square value & Interpretation \\
\hline Attitude towards ICT-based teaching & 5.96 & Not significant \\
Perceived readiness to use ICT in teaching & 2.44 & Not significant \\
ICT Practices for educational purposes & 2.87 & Not significant \\
\hline
\end{tabular}

The figures above are way below the $\chi 2$ critical value of 12.59 with 6 degree of freedom at $\alpha=$ 0.05. The levels of knowledge of the pre-service teachers regarding ICT-based teaching drawn from the grades of the pre-service teachers in Educational Technology 2 do not significantly 
relate with their attitudes, perceived readiness, and ICT practices. The curricular activities may not be strong enough to influence them in the said variables.

The result only shows that the pre-service teachers' knowledge on ICT-based teaching has no relationship with their attitudes, perceived readiness, and ICT practices. On the other way around, the said variables do not influence the pre-service teachers' knowledge on ICT-based teaching. Thus, their knowledge on ICT-based teaching is independent from the said variables.

Geiser and Futrell (2000) propose that the technological curricula (e.g. EdTech 2) should commit to gear students' attitudes to lean to developing oneself in using technology to think better, feel better, and do better. If achievements in the educational technology courses do not significantly relate with students' attitude, readiness and practices, there might be some missing link in the syllabi.

Further in this study, no matter which level a pre-service teacher would be, his/her perceived readiness and technological practices will not differ. Above average performers may simply feel the same and do the same as those in the average and below average groups. These ideas may suggest that the present curricular tasks in the said courses are not that responsive to equip the pre-service teachers of the necessary attitude, readiness and practices to be ICTbased teachers in the future.

\section{CONCLUSIONS AND RECOMMENDATIONS}

From the findings, the study concludes that the pre-service teachers have favorable attitude towards the use of ICT in teaching. Moreover, they are very good at using ICT for educational purposes. However, they are moderately ready for ICT-based teaching. Further, the pre-service teachers' knowledge on ICT-based instruction does not influence their attitudes towards ICTbased teaching, perceived readiness on the use of ICT in teaching, and ICT practices. Thus, this study offers several recommendations.

Teachers handling educational technology courses in the school should revisit their syllabus in EdTech 2. They should revise or modify their syllabus in a way that it should commit to gear students' attitudes to lean to developing oneself in using technology to think better, feel better, and do better. Pre-service teachers should not only be taught of the theories and principles related to ICT but also the actual use of ICT tools alongside with the theories and principles.

Conducting demonstration teaching in ICT-based teaching among pre-service teachers is recommended in the curriculum to prepare them for actual teaching. Thus, teachers in EdTech 2 should collaborate with teachers in Principles of Teaching to empower the pre-service teachers' teaching skills in the use of ICT. In this way, the pre-service teachers will become more prepared to use ICT tools in ICT-based teaching.

Finally, it is recommended that a framework may be developed and be proposed as a basis for Teacher Education Institutions to encourage, empower, and equip pre-service teachers to become adaptive basic education teachers using the ICT-based teaching principles responsive to the demands of the 21 st century.

\section{Literature Cited}

Ary, Donald, et.al. (2002). Introduction to Research in Education (6th edition). Wadsworth/Thompson Learning, 10 Davis Drive, 2nd Floor Stamford, CT 06902-7477 USA. 
Best, John W. \& Khan, James V. (2003). Research in Education (9th edition). Pearson Education South Asia Pte. Ltd., 23-25 First Lok Yang Road, Jurong, Singapore 629733.

Corpuz, Brenda B. \& Lucido, Paz I. (2008). Educational Technology 1. Lorimar Publishing Inc., 776 Aurora Blvd., Cubao, Quezon City, Philippines.

Darbyshire, Paul (2005). Instructional Technologies: Cognitive Aspects of Online Programs. IRM Press, PA, USA \& London, UK.

Garo, Candelaria D. (2008). Theories and Principles of Educational Technology. National Bookstore. Quezon City, Philippines.

Geisert, Paul G. \& Futrell, Mynga K. (2000). Teachers, Computers, and Curriculum: Microcomputers in the Classroom. Allyn \& Bacon, A Pearson Education Company, 75 Arlington Street, Boston, MA 02116 (USA).

Kallick, Bena \& Wilson, James III M. (2001). Information Technology for Schools: Creating Practical Knowledge to Improve Student Performance. Jossey-Bass Inc., 350 Sansome Street, San Francisco, California 94104.

Kearsley, Greg (2000). Online Education: Learning and Teaching in Cyberspace. Wadsworth/Thompson Learning, 10 Davis Drive, 2nd Floor Stamford, CT 06902-7477 USA.

Lucido, Paz I. \& Borabo, Milagros L. (2007). Educational Technology. Katha Publishing Co., Inc., 388 Quezon Ave., Quezon City, Philippines.

Lucido, Paz I. (2007). Educational Technology 2, Lorimar Publishing Inc., 776 Aurora Blvd., Cubao, Q.C., Philippines.

Maier, Pat, et.al. (1998). Using Technology in Teaching and Learning. Interactive Learning Centre, University of Southampton \& Kogan Page Limited, 120 Petonville Road, London Ni 9JN \& 22883 Quicksilver Drive Stirling, VA 20166, USA.

Morrison, Gary R. \& Lowther, Deborah L. (2005). Integrating Computer Technology into the Classroom (3rd Edition). Pearson Education, Inc., Upper Saddle River, New Jersey 07458 USA. 